\title{
Naturally enhanced eggs as a source of vitamin D
}

\section{A review}

\section{Barnkob, Line Lundbæk; Argyraki, Aikaterini; Jakobsen, Jette}

\section{Published in:}

Trends in Food Science and Technology

Link to article, DOI:

10.1016/j.tifs.2020.05.018

Publication date:

2020

Document Version

Peer reviewed version

Link back to DTU Orbit

Citation (APA):

Barnkob, L. L., Argyraki, A., \& Jakobsen, J. (2020). Naturally enhanced eggs as a source of vitamin D: A review. Trends in Food Science and Technology, 102, 62-70. https://doi.org/10.1016/j.tifs.2020.05.018

\section{General rights}

Copyright and moral rights for the publications made accessible in the public portal are retained by the authors and/or other copyright owners and it is a condition of accessing publications that users recognise and abide by the legal requirements associated with these rights.

- Users may download and print one copy of any publication from the public portal for the purpose of private study or research.

- You may not further distribute the material or use it for any profit-making activity or commercial gain

- You may freely distribute the URL identifying the publication in the public portal

If you believe that this document breaches copyright please contact us providing details, and we will remove access to the work immediately and investigate your claim 


\section{Journal Pre-proof}

Naturally enhanced eggs as a source of vitamin D: A review

Line Lundbæk Barnkob, Aikaterini Argyraki, Jette Jakobsen

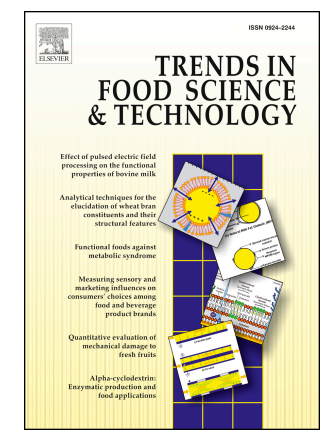

PII: $\quad$ S0924-2244(20)30479-9

DOI: $\quad$ https://doi.org/10.1016/j.tifs.2020.05.018

Reference: TIFS 2863

To appear in: Trends in Food Science \& Technology

Received Date: 3 May 2019

Revised Date: 6 May 2020

Accepted Date: 21 May 2020

Please cite this article as: Barnkob, Line.Lundbæ., Argyraki, A., Jakobsen, J., Naturally enhanced eggs as a source of vitamin D: A review, Trends in Food Science \& Technology (2020), doi: https:// doi.org/10.1016/j.tifs.2020.05.018.

This is a PDF file of an article that has undergone enhancements after acceptance, such as the addition of a cover page and metadata, and formatting for readability, but it is not yet the definitive version of record. This version will undergo additional copyediting, typesetting and review before it is published in its final form, but we are providing this version to give early visibility of the article. Please note that, during the production process, errors may be discovered which could affect the content, and all legal disclaimers that apply to the journal pertain.

() 2020 Published by Elsevier Ltd. 


\section{Abstract}

Background: It is estimated that on annual basis $40 \%$ of the European population is either vitamin D insufficient/deficient. A way to increase the vitamin D intake is to fortify a broader range of foods or by increasing the natural vitamin D content in food sources that already contain vitamin D. Eggs is once again considered part of a healthy varied diet and eggs contain a wide range of micro nutrients including vitamin D.

Scope and Approach: Review of production methods to naturally enhance eggs with vitamin D, and discussion of the perspectives of vitamin D enhanced eggs as part of the strategy to increase the dietary intake of vitamin D.

Key Findings and Conclusions: There are three ways to naturally enhance the vitamin D content in eggs: feeding more vitamin $\mathrm{D}_{3} / 25(\mathrm{OH}) \mathrm{D}_{3}$ to the hens, exposing the hens to UVB and exposing liquid egg products to UVB. Naturally enhanced eggs can contribute to increased vitamin D intake. An inter-trial linear relationship between vitamin $\mathrm{D}_{3}$ in feed and vitamin $\mathrm{D}_{3}$ in eggs was found. Within the linear range a maximum of $20 \mu \mathrm{g} / 100 \mathrm{~g}$ yolk was obtained with feed contain $617.5 \mu \mathrm{g} / \mathrm{kg}$ feed. Feed can provide higher levels of vitamin D in eggs than UVB exposure of the hens. However, the European maximum for vitamin D in feed for layers at $80 \mu \mathrm{g} / \mathrm{kg}$ limits the beneficial effect. Vitamin D content in liquid egg products can be tailored by adjusting the UVB dose, however further research is needed.

\section{Keywords}

Vitamin $\mathrm{D}_{3}$; fortification;25-hydroxyvitamin $\mathrm{D}_{3}$; hens; UVB; feed 


\section{Naturally enhanced eggs as a source of vitamin D: A review}

2 Line Lundbæk Barnkob ${ }^{\mathrm{a}}$, Aikaterini Argyraki ${ }^{\mathrm{b}}$ and Jette Jakobsen ${ }^{\mathrm{a} *}$

3

$4 \quad{ }^{a}$ National Food Institute, Technical University of Denmark, Research Group for Bioactives - Analysis and

5 Application, Kemitorvet, 2800 Kgs. Lyngby, Denmark

$6{ }^{\mathrm{b}}$ Technical University of Denmark, Department of Photonics Engineering, DTU Ris $\varnothing$ campus,

$7 \quad$ Frederiksborgvej 399, 4000 Roskilde, Denmark

8

$9 *$ Corresponding author

10 E-mail: jeja@food.dtu.dk (J. Jakobsen)

11

12 


\section{Introduction}

15

It is estimated that on annual basis $40 \%$ of the European population is either vitamin D insufficient (< $50 \mathrm{nmol} / \mathrm{L}$ total serum 25-hydroxyvitamin D (25(OH)D) or deficient (<30 nmol/L) (Cashman et al., 2016). Although there is dispute about where to set the limit of insufficiency and deficiency, there is agreement that the vitamin D status (total serum 25(OH)D) of the general population has to be increased (Holick, 2017). Vitamin D can be obtained either through food or sun exposure, where sun exposure is the major contributor to vitamin D in humans. 7-dehydrocholesterol (7-DHC) in the skin is converted to previtamin $\mathrm{D}_{3}$ when the skin is exposed to wavelengths between 290 and $315 \mathrm{~nm}$ (ultraviolet $\mathrm{B}, \mathrm{UVB}$ ) and previtamin $\mathrm{D}_{3}$ is then converted to vitamin $\mathrm{D}_{3}$ by thermal isomerization at body temperature (Holick et al., 1980;

MacLaughlin, Anderson, \& Holick, 1982); vitamin $\mathrm{D}_{3}$ is transported to the liver where it is converted to 25hydroxivitamin $\mathrm{D}_{3}\left(25(\mathrm{OH}) \mathrm{D}_{3}\right)$ (Christakos, Dhawan, Verstuyf, Verlinden, \& Carmeliet, 2016). However, from October through March at $52^{\circ} \mathrm{N}$ no cutaneous vitamin $\mathrm{D}$ is produced as most of the solar photons below $315 \mathrm{~nm}$ is attenuated by the longer travel through the ozone layer during the so-called vitamin $\mathrm{D}$ winter (Webb, 2006; Webb, DeCosta, \& Holick, 1989; Webb, Kline, \& Holick, 1988). The duration of the vitamin D winter decreases with decreasing latitude and according to UVB data it is suggested that the duration is: 5 months in UK, Ireland and the Netherlands; 6 months in Denmark; 8 months in the north of Norway; while it is 2 to months in Greece and 0 in Crete (O'Neill et al., 2016).

Vitamin D exists in two forms: vitamin $\mathrm{D}_{2}$ and vitamin $\mathrm{D}_{3}$. Although there are multiple metabolites of vitamin $\mathrm{D}$, only vitamin $\mathrm{D}$ and its major metabolite $25(\mathrm{OH}) \mathrm{D}$ is considered when determining the total vitamin D content in food (Ovesen, Brot, \& Jakobsen, 2003). Vitamin $\mathrm{D}_{3}$ and $25(\mathrm{OH}) \mathrm{D}_{3}$ is found in food of animal origin, such as fish, meat, offal, eggs, milk and dairy products (Ovesen et al., 2003). Vitamin $\mathrm{D}_{2}$ is found in yeast, mushrooms, and fortified milk and dairy products (Keegan, Lu, Bogusz, Williams, \& Holick, 2013). 
The recommended intake of vitamin D varies for the different age groups, and between the individual organisations setting the guidelines (Boiullion, 2017). In Europe and US, the guidelines for adults are between 10 and $20 \mu \mathrm{g} /$ day (Institute of Medicine, 2011; EFSA, 2016; Nordic Council of Ministers, 2012), however the estimated intake is 3 to $7 \mu \mathrm{g} / \mathrm{day}$ (Cashman \& Kiely, 2016). In some countries with mandatory fortification programmes the intake of vitamin D is still suboptimal (Lehtonen-Veromaa et al., 2008; Whiting, Green, \& Calvo, 2007). Since 2003 Finland have had a voluntary fortification programme which includes milk and fat spread with the effect that the adult population who have a diet based on nutritional recommendations have a sufficient vitamin D status, while the status in adolescent girls is still insufficient (Jääskeläinen et al., 2017; Lehtonen-Veromaa et al., 2008)

A way to increase the vitamin D intake is to fortify a broader range of foods or by increasing the natural vitamin D content in food sources that already contain vitamin D (Barnkob, Argyraki, Petersen, \& Jakobsen, 2016; Black, Seamans, Cashman, \& Kiely, 2012; Cashman \& Kiely, 2016; Kiely \& Black, 2012; O’Mahony, Stepien, Gibney, Nugent, \& Brennan, 2011). Foods with natural increased vitamin D content could in some cases be more broadly accepted by consumers (Cashman, 2015).

For many years eggs have had a bad reputation due to a high content of cholesterol, however as reviewed by Gray (2018), eggs were wrongfully accused and is once again considered to be part of a healthy varied diet as they contribute with a range of micro nutrients, including vitamin $\mathrm{D}$, and high quality, easily digestible proteins; and compared to other food sources eggs are easily prepared, they are relatively cheap and they are included in the diet of the majority of the population (Gray, 2018; Mejborn, Jacobsen, \& Trolle, 2011; Pedersen et al., 2015).

The principle in the analytical methods used for quantification of vitamin D has since the introduction of an internal standard been the same (Indyk and Wollard, 1985), i.e. alkaline saponification, liquid-liquid extraction, clean-up step (preparative HPLC or/and solid-phase-extraction), and separation by HPLC combined with UV-/DAD-detector. Method for quantification of 25-hydroxyvitamin D was introduced at a later stage by applying the same principle (Mattila et al. 1995). A huge improvement in especially sensitivity and laboratory work came with the introduction of mass spectrometry detection (Dimartino, G, 2009). Due to the relatively high amount of vitamin D in eggs, the analytical improvement is essential for the amount of 
sample taken for analysis and the cost of an analysis, as a technician in 1990's could run 10 samples a week, a technician in 2020 may run 20 samples a day. Otherwise the improvement, did not affect the trueness of the methods, which essentially is due the use of internal standard. Thus, making it possible to combine old and new analytical data in this review.

The natural content of vitamin D in eggs can be increased by three methods, of which two have gained the most attention: adding more vitamin D to the feed of the hens; and exposing the hens to UVB light. The third method is to expose egg yolk directly to UVB. We will review the literature on these three methods and discuss their future perspectives.

\section{Method}

An extensive literature search was performed in January 2019. The search machine DTU Findit (DTU Library, n.d.) was used with the following search phrase: vitamin D OR eggs OR ultraviolet OR content OR yolk. Reference lists from relevant articles found in the search as well as the cited by function in Google were used to find additional references.

In order to make different reported results comparable all results have been recalculated to $\mu \mathrm{g} / 100 \mathrm{~g}$ egg for vitamin $\mathrm{D}_{3}$ and $25(\mathrm{OH}) \mathrm{D}_{3}$; and $\mu \mathrm{g} / \mathrm{kg}$ for vitamin $\mathrm{D}_{3}$ and $25(\mathrm{OH}) \mathrm{D}_{3}$ in feed. Some authors report the results per gram egg yolk, in these cases the data has been recalculated under the assumption that a whole egg consists of $33 \%$ yolk (Mattila, Lehikoinen, Kiiskinen, \& Piironen, 1999; Mattila, Valkonen, \& Valaja, 2011). Others have reported results per gram dry matter of egg yolk, it is assumed that an egg yolk contain 7 g of dry matter (DTU Food, 2018; Kühn et al., 2015; Schutkowski et al., 2013) based on an average egg yolk weight of $15 \mathrm{~g}$. It is assumed that vitamin D is only present in the yolk.

To make UVB doses comparable all reported values have been recalculated to $\mathrm{J} / \mathrm{m}^{2}$. 
This review will primarily focus on the vitamin D content, if interested in how vitamin D and its metabolites affect performance and egg quality we refer to a recent review from Światkiewicz, Arczewska-Wlosek, Bederska-Lojewska, \& Józefiak (2017).

Vitamin $\mathrm{D}_{2}$ is not as effectively transferred to yolk as vitamin $\mathrm{D}_{3}$ (Francis G. McDonald \& Massengale, 1932), and only vitamin $\mathrm{D}_{3}$ and $25(\mathrm{OH}) \mathrm{D}_{3}$ is approved as vitamin $\mathrm{D}$ additives in feed for layers; therefore studies performed with vitamin $\mathrm{D}_{2}$ are not included except for Kawazoe, Yuasa, Yamazaki, \& Ando (1994) who studied the relation between feed intake and vitamin D content in eggs which have not been studied using vitamin $\mathrm{D}_{3}$.

A lot of studies were published in the 1920 'ties and 1930'ties regarding how to increase the vitamin D content in eggs. It was shown that the content of vitamin D in egg yolk could be increased by adding vitamin D to the feed of laying hens (Bethke, Kennard, \& Sassaman, 1927; Branion, Drake, \& Tisdall, 1935; DeVaney, Munsell, \& Titus, 1933; Guerrant, Kohler, Hunter, \& Murphy, 1935) or by irradiating nonsupplemented hens from above (Farrell, 1924; Hart et al., 1925; Hendricks, 1931; Hughes \& Payne, 1924; Hughes, Payne, Titus, \& Moore, 1925; Maughan \& Maughan, 1933). However, when Carson \& Beall (1955) supplemented hens with approximately $29 \mu \mathrm{g}$ vitamin D/kg feed and exposed them to UVB from above, no increase of vitamin D in the eggs were observed. The vitamin D content in these studies of older date was determined by hatchability of eggs,an endpoint, which is based on the fact that vitamin D in egg yolk is essential for embryonic survival (Sunde et al., 1978), or by animal assays where the total vitamin D activity is determined. Only studies that measure the individual content of vitamin $\mathrm{D}_{3}$ and/or $25(\mathrm{OH}) \mathrm{D}_{3}$ have been included.

Two studies were excluded as they also included increased content of vitamin $\mathrm{K}$ in the feed (Park, Namkung, Ahn, \& Paik, 2005; Zang et al., 2011). At high concentration vitamin K inhibits the uptake of vitamin D (Reboul, 2015) and as both vitamin D and vitamin K are involved in bone health (Torbergsen et al., 2015) it cannot be ruled out that they also interact at higher levels in vivo.

\section{Bioavailability of vitamin D from eggs}


As mentioned in the introduction eggs are an optimal vehicle for vitamin D in regard to its nutritional qualities and wide use. A recent review found no difference in the bioavailability of vitamin $\mathrm{D}_{3}$ from fortified food compared to supplements (Borel, Caillaud, \& Cano, 2015). Investigation of the bioavailability of vitamin $\mathrm{D}_{3}$ and $25(\mathrm{OH}) \mathrm{D}_{3}$ from natural food is limited, but no difference was shown for vitamin $\mathrm{D}_{3}$ from cod liver oil and vitamin $\mathrm{D}_{3}$ in multivitamin tables to increase vitamin D status (Holvik, Madar, Meyer, Lofthus, $\&$ Stene, 2007). Moreover, it has been shown than intake of vitamin D enhanced eggs is associated with increased vitamin D status (Hayes et al., 2016).

\section{Cooking loss of vitamin $D$ in eggs}

Two studies regarding the loss of vitamin D during cooking of eggs have been published (Jakobsen \& Knuthsen, 2014; Mattila, Ronkainen, Lehikoinen, \& Piironen, 1999). Vitamin D and 25(OH)D in eggs will be lost, to the same extent, during household cooking: A hardboiled egg (10 minutes of cooking) will lose around $10 \%$ of both vitamin $\mathrm{D}$ and $25(\mathrm{OH}) \mathrm{D}$, scrambling an egg for 3 minutes gives less than $20 \%$ loss of both, while during baking for 40 minutes around $60 \%$ of both is lost (Jakobsen \& Knuthsen, 2014; Mattila, Ronkainen, et al., 1999).

\section{European legislation regarding vitamin $D$ in feed for laying hens}

The legal limit for adding vitamin $\mathrm{D}_{3}, 25(\mathrm{OH}) \mathrm{D}_{3}$ or a combination of the two to feed is $80 \mu \mathrm{g} / \mathrm{kg}$ for laying hens in Europe (Commission Regulation (EU) 2017/1492 Commission Regulation (EC) No 887/2009); according to Commission Regulation (EU) 2017/1492 this level does not have adverse effects on animal health, human health or the environment based on scientific opinions from the European Food Safety Authority (EFSA). The reasoning behind EFSAs conclusion regarding animal safety was that this level has been used for over a decade without any reported intolerances (EFSA, 2014); they were however unable to draw any final conclusion as their answer was solely based on data from the National Research Council 
(NRC) from 1987. In regard to human health, they conclude that as there has been no change in the level of vitamin $D$ in feed during the last decade it is safe to continue with the same level (EFSA, 2014). The fact that the human intake of vitamin D is below the recommended was not taken into consideration.

\section{Vitamin D content in commercial feed for laying hens}

In 2014 one of the major producers of feed for laying hens in Denmark used $75 \mu \mathrm{g}$ vitamin $\mathrm{D}_{3}$ per $\mathrm{kg}$ feed (personal communication with Danish Agro). A survey from 1996 conducted in USA showed that the average content of vitamin $\mathrm{D}_{3}$ in feed for laying hens was $61.5 \mu \mathrm{g} / \mathrm{kg}$ feed (BASF, 1998), while in China the average level is $60 \mu \mathrm{g} / \mathrm{kg}$ feed (Zang et al., 2011).

How common the use of $25(\mathrm{OH}) \mathrm{D}_{3}$ in feed has become since it was legalized in 2009 in Europe is unknown but Mattila et al. (2011) concluded from their investigations of commercial eggs that egg producers in Finland so far continued to use vitamin $\mathrm{D}_{3}$ as the only vitamin D supplement, however in 2011 one producer in Denmark launched an egg where $25(\mathrm{OH}) \mathrm{D}_{3}$ was used in the feed (Hedegaard, n.d.) and Liu, Greenfield, \& Fraser (2014) analysed eggs from an Australian producer known to use a combination of $25(\mathrm{OH}) \mathrm{D}_{3}$ and vitamin $\mathrm{D}_{3}$.

\section{Vitamin D content in commercial eggs}

The content of vitamin $\mathrm{D}_{3}$ and $25(\mathrm{OH}) \mathrm{D}_{3}$ in commercial eggs reported by various sources since 1982 is displayed in Error! Reference source not found.. On average the content of vitamin $\mathrm{D}_{3}$ and $25(\mathrm{OH}) \mathrm{D}_{3}$ in commercial eggs is $1.5 \mu \mathrm{g} / 100 \mathrm{~g}$ and $0.5 \mu \mathrm{g} / 100 \mathrm{~g}$, respectively.

\section{Effect of enhancing vitamin $D$ content through feed}


Vitamin $\mathrm{D}$ in feed can be given either as vitamin $\mathrm{D}_{3}, 25(\mathrm{OH}) \mathrm{D}_{3}$ or a combination of the two. Hens have a binding protein for vitamin $\mathrm{D}_{3}$ in the plasma that forms a complex that is actively transported into yolk; however this binding protein also has a small affinity for $25(\mathrm{OH}) \mathrm{D}_{3}$ and when $25(\mathrm{OH}) \mathrm{D}_{3}$ is present in high concentrations it can displace vitamin $\mathrm{D}_{3}$ and thereby be actively transported into yolk (Fraser \& Emtage, 1976). When feeding vitamin $\mathrm{D}_{3}$ the content of both vitamin $\mathrm{D}_{3}$ and $25(\mathrm{OH}) \mathrm{D}_{3}$ in the egg will increase, however using $25(\mathrm{OH}) \mathrm{D}_{3}$ alone will not increase the vitamin $\mathrm{D}_{3}$ content of the egg (Browning \& Cowieson, 2014); and when fed a combination the displacement of vitamin $\mathrm{D}_{3}$ by $25(\mathrm{OH}) \mathrm{D}_{3}$ mentioned above is assumed to be minimal. Therefore, studies that use a combination have been included in assessing the impact feeding vitamin $\mathrm{D}_{3}$ has on the vitamin $\mathrm{D}_{3}$ content in eggs.

When starting a new feeding regime it will take some time before the vitamin $\mathrm{D}_{3}$ content in the eggs reach a stable plateau (equilibration). The equilibration time is reported to be between 8 days and 3 weeks and it is independent of the vitamin $\mathrm{D}_{3}$ content of the feed; and when an equilibrium is reached the content stays relatively stable (Mattila et al., 2003; Park et al., 2005; Yao, Wang, Persia, Horst, \& Higgins, 2013). The duration of the studies feeding vitamin $\mathrm{D}_{3}$ was between 2 weeks and 48 weeks while for $25(\mathrm{OH}) \mathrm{D}_{3}$ it was between 4 and 9 weeks.

The age of the hens varies between trials, but Mattila et al. (2003) found that age does not have an effect on the transfer of vitamin $\mathrm{D}_{3}$ from feed to the egg and it is assumed that this holds true for $25(\mathrm{OH}) \mathrm{D}_{3}$ as well. A variation of commercial breeds, both white and brown, has been used.

It should be noted that the reported values are averages and that the content in the individual eggs will vary as the feed intake per hen varies. Kawazoe et al. (1994) found an average feed intake of $117 \mathrm{~g} \pm 7.6 \mathrm{~g}$ (standard deviation, SD) and they showed a linear relationship between vitamin D content in the egg and the feed intake; within a group the vitamin D content varied between 7-11 $\mu \mathrm{g} / 100 \mathrm{~g}$ and the coefficient of variance $(\mathrm{CV})$ of the mean was $15 \%^{1}$. Kawazoe et al. (1994) used irradiated shitake and thereby $\mathrm{D}_{2}$, but it is assumed that relation will be the same for vitamin $\mathrm{D}_{3}$ and $25(\mathrm{OH}) \mathrm{D}_{3}$. The $\mathrm{CV} \%$ of vitamin $\mathrm{D}_{3}$ and $25(\mathrm{OH}) \mathrm{D}_{3}$ determined in egg yolk, fed a combination of the two, were comparable with an average CV of $24 \%$

\footnotetext{
${ }^{1}$ Approximately values as they are calculated from data points in Figure 6 in the paper.
} 
(Browning \& Cowieson, 2014). Genetic differences between birds are most likely also a contributor to the observed variance (Browning \& Cowieson, 2014).

\subsection{Effect of using vitamin $D_{3}$ as feed additive}

We found eight studies where hens have been fed vitamin $\mathrm{D}_{3}$ at levels between $26.6 \mu \mathrm{g} / \mathrm{kg}$ and 2555 $\mu \mathrm{g} / \mathrm{kg}$ (Browning \& Cowieson, 2014; Hayes et al., 2016; Kawazoe, Yuasa, Noguchi, Yamazaki, \& Ando, 1996; Mattila et al., 2003; Mattila, Valaja, Rossow, Venäläinen, \& Tupasela, 2004; Mattila, Lehikoinen, et al., 1999; Plaimast, Kijparkorn, \& Ittitanawong, 2015; Yao et al., 2013).

The transfer efficiency $\left(=\left[\right.\right.$ vitamin $\mathrm{D}_{3}$ in yolk $\bullet$ yolk weight $\bullet$ egg production per hen per day $] /[$ vitamin $\mathrm{D}_{3}$ in feed $\bullet$ feed intake per hen per day $\left.\bullet 100\right]$ ) of vitamin $\mathrm{D}_{3}$ from diet to egg was determined by Kawazoe et al. (1996) and Yao et al. (2013). The data from the two studies have shown that the transfer efficiency increases when the content in feed is increased: it is $7-8 \%$ when using $55 \mu \mathrm{g} / \mathrm{kg}$ feed; $11-14 \%$ when using 242.5-617.5 $\mu \mathrm{g} / \mathrm{kg}$; and 41-47 \% when using $2555 \mu \mathrm{g} / \mathrm{kg}$. Yao et al. (2013) also calculated transfer

efficiencies using data from other studies where similar levels of supplementation was used and the results were within the ranges given above.

In long term trials ( $\geq 24$ weeks) no negative health effects of feeding 300 to $2555 \mu \mathrm{g}$ vitamin $\mathrm{D}_{3} / \mathrm{kg}$ feed have been observed (Mattila et al., 2003, 2004; Persia, Higgins, Wang, Trample, \& Bobeck, 2013). Reduced feed intake, egg weight, shell quality and fertility have been reported for laying hens fed with 5000 $\mu \mathrm{g} / \mathrm{kg}$ (Ameenuddin, 1986).

The vitamin $D_{3}$ content in eggs as a function of the content vitamin $D_{3}$ in feed is displayed in Figure 1 . There is a linear relationship between the vitamin $\mathrm{D}_{3}$ content in the feed and the content of vitamin $\mathrm{D}_{3}$ in the egg with a Pearson correlation coefficient (Pearson's r) of 0.987 and a p-value of $6 \bullet 10^{-19}$ (F-test) in spite of the differences in the design of the studies. The equation for the linear regression is:

Vitamin $D_{3}$ in eggs $(\mu \mathrm{g} / 100 \mathrm{~g})=0.033 \bullet \operatorname{vitamin} \mathrm{D}_{3}$ in feed $(\mu \mathrm{g} / \mathrm{kg})-0.58$ 
The linear range covers up to $617.5 \mu \mathrm{g} / \mathrm{kg}$ feed and the highest vitamin D content in eggs is 40 times higher than the lowest. Yao et al. (2013) fed $2555 \mu \mathrm{g} / \mathrm{kg}$ feed to one of their treatment groups and the resulting vitamin $\mathrm{D}_{3}$ content was $287 \mu \mathrm{g} / 100 \mathrm{~g}$; this result is not included in Figure 1 as it is outside the linear range; the expected content from the linear regression would be $84 \mu \mathrm{g} / 100 \mathrm{~g}$. This fits with the observation that the transfer efficiency increases with increased content of vitamin $\mathrm{D}_{3}$ in the feed (Kawazoe et al., 1996; Yao et al., 2013).

The $25(\mathrm{OH}) \mathrm{D}_{3}$ content in eggs as a function of vitamin $\mathrm{D}_{3}$ in feed is better described by a logarithmic equation (black line in Figure 2) with a Pearson's $r$ of 0.6 compared to 0.47 for the linear relationship (dotted line in Figure 2). However, the data is limited and the p-value for the F-test of the regression of the logtransformed data is 0.08 . The only conclusion that can be draw is that $25(\mathrm{OH}) \mathrm{D}_{3}$ content in eggs will increase with increased supplementation of vitamin $\mathrm{D}_{3}$ but to a lesser degree than what is observed for the vitamin $\mathrm{D}_{3}$ content in eggs.

\subsection{Effect of using $25(\mathrm{OH}) \mathrm{D}_{3}$ as feed additive}

We have found six studies that report on the vitamin D content of eggs after hens have been fed $25(\mathrm{OH}) \mathrm{D}_{3}$ alone or in combination with vitamin $\mathrm{D}_{3}$ (Browning \& Cowieson, 2014; Duffy et al., 2017; EFSA, 2005; Hayes et al., 2016; Koshy \& Van Der Slik, 1979; Mattila et al., 2011).

Figure 3 shows the $25(\mathrm{OH}) \mathrm{D}_{3}$ content in eggs from hens that have been fed solely $25(\mathrm{OH}) \mathrm{D}_{3}$. From Figure 3 it is seen that only two studies have used at least two levels and that Mattila et al. (2011) is the only of the two that shows a significant increase; however, with a Pearson's $r$ of 0.6 there is not the same linear inter-trial tendency as shown for vitamin $\mathrm{D}_{3}$, but the limited amount of data should be taken into consideration. The dose-response is moderate compared to what is observed for vitamin $\mathrm{D}_{3}$; the slope of the linear regression is 0.0093 which is approximately a factor 3 lower than the vitamin $\mathrm{D}_{3}$ slope (see section 8.1).

Only two studies used doses above the legal limit of $80 \mu \mathrm{g} / \mathrm{kg}$. Terry, Lanenga, McNaughton, \& Stark (1999) supplemented laying hens with 41, 83, 413 and $825 \mu \mathrm{g} 25(\mathrm{OH}) \mathrm{D}_{3}$ per $\mathrm{kg}$ feed for 224 days, however 
eggs were analysed for vitamin D content after 112 days. No mortality was observed at any level. Based on decreased production parameters $825 \mu \mathrm{g}$ were toxic while $413 \mu \mathrm{g} 25(\mathrm{OH}) \mathrm{D}_{3}$ per $\mathrm{kg}$ feed were just above the margin of the no effect level and for this reason the results of these two treatments are left out of Figure 3. Eggs from hens fed $413 \mu \mathrm{g} / \mathrm{kg}$ had a $25(\mathrm{OH}) \mathrm{D}_{3}$ content of $2.4 \mu \mathrm{g} / 100 \mathrm{~g}$ (Terry et al., 1999), therefore this could be considered to be the maximum obtainable level when using $25(\mathrm{OH}) \mathrm{D}_{3}$ as the only vitamin source. Mattila et al. (2011) fed hens with $122 \mu \mathrm{g} 25(\mathrm{OH}) \mathrm{D}_{3} / \mathrm{kg}$ feed during 6 weeks without observing any negative effects on the egg shell quality.

Based on the results presented in Terry et al. (1999) $80 \mu \mathrm{g} / \mathrm{kg}$ was set as the safe level in the scientific opinion from EFSA regarding the use of $25(\mathrm{OH}) \mathrm{D}_{3}$ in feed (EFSA, 2005).

Three studies used a combination of $25(\mathrm{OH}) \mathrm{D}_{3}$ and vitamin $\mathrm{D}_{3}$ (Browning \& Cowieson, 2014; Duffy et al., 2017; Mattila et al., 2011); the results are displayed in Figure 4. From the results of Browning \& Cowieson (2014) ([2] in Figure 4) it can be seen that increasing the $25(\mathrm{OH}) \mathrm{D}_{3}$ supplementation while keeping the vitamin $\mathrm{D}_{3}$ supplementation unchanged will give increased $25(\mathrm{OH}) \mathrm{D}_{3}$ content in eggs. Feeding a combination of $250 \mu \mathrm{g}$ vitamin $\mathrm{D}_{3}$ and $69 \mu \mathrm{g} 25(\mathrm{OH}) \mathrm{D}_{3}$ results in a $25(\mathrm{OH}) \mathrm{D}_{3}$ content of $2.7 \mu \mathrm{g} / 100 \mathrm{~g}$ in the eggs; this exceeds the maximum that can be obtained by feeding $25(\mathrm{OH}) \mathrm{D}_{3}$ alone.

\section{Enhancement using artificial UVB}

\subsection{Location and content of 7-DHC in hens}

The legs and feet of hens have the highest content of 7-DHC when compared to the feathered part of the hens and the comb. Koch \& Koch (1941) found that skin from the legs and feet of chicken had approximately 8 times as much 7-DHC compared to the body. Tian, Chen, Lu, Shau, \& Holick (1994) measured the content of 7-DHC in various parts of the chicken skin. They found that the 7-DHC content in skin on the legs and feet were 29 and 23 times higher than the content in the back skin. After irradiation with $5000 \mathrm{~J} / \mathrm{m}^{2}$ no pre-vitamin $\mathrm{D}_{3}$ was detected in the back skin (Tian et al., 1994). Schutkowski et al. (2013) 
found that the 7-DHC concentration in the un-feathered legs was 190 times higher than the concentration in the comb; the lowest concentration was found in the feathered parts of the hen. Edwards (2003) irradiated young chickens with UVB and looked at growth and bone development; he found that exposure from below was more than twice as effective as from above.

Uva, Mandich, \& Vallarino (1983) found that vitamin $\mathrm{D}_{3}$ concentration was 3 times higher in the uropygial gland (an oil gland located just above the base of the tail feathers) than in the unfeathered skin from the legs and concluded that this is the major site for production of vitamin $\mathrm{D}_{3}$ (from 7-DHC). They also found vitamin $\mathrm{D}_{3}$ in the extracts of feathers, the origin was hypothesized to be from the gland and that the oil was spread in the act of preening. Tian et al. (1994) found 7-DHC in lipid extracts from feathers; this could originate from the uropygial gland as Uva et al. (1983) hypothesized as the major production site of 7-DHC.

\subsection{Effect of exposing hens to UVB from above}

It has been shown possible to increase vitamin $\mathrm{D}$ in eggs when irradiating hens from above, if the hens do not receive vitamin D through the feed (Chiang, Hwang, \& Holick, 1996, 1997). However, Lietzow et al. (2012) irradiated layers, with UVB light in the range of 280-310 $\mathrm{nm}$ for 4 weeks from above, with a dose of $540 \mathrm{~J} / \mathrm{m}^{2} /$ day. Both non-supplemented hens and hens supplemented with $75 \mu \mathrm{g}$ vitamin $\mathrm{D}_{3} / \mathrm{kg}$ feed were exposed. They found no effect of UVB exposure on the content of vitamin D in eggs. However, as no increase was observed in the non-supplemented group, as would have been expected from the trials of Chiang et al. $(1996,1997)$ and older findings, the dose might have been too low. We have repeated the trial of Lietzow et al. (2012) with a dose of $547 \mathrm{~J} / \mathrm{m}^{2} /$ day using UVB light emitting diodes (LED) with a central wavelength of $307 \pm 2 \mathrm{~nm}$ (standard deviation) which should be more optimal for vitamin $\mathrm{D}_{3}$ production (Barnkob et al., 2016); the outcome was however the same (Argyraki, 2017). We also tried with a dose of $4000 \mathrm{~J} / \mathrm{m}^{2} /$ day, however, the treatment was stopped after 7 days as changes of the comb was observed and interpreted as erythema; in retrospect the changes could be harmless as free-range hens have more red and stiff comb than hens secluded from sunlight. Eggs collected before UVB exposure had a content of 1.1 
$\mu \mathrm{g} / 100 \mathrm{~g}$ while eggs collected after 7 days of exposure, where the treatment was stopped, had a vitamin $\mathrm{D}_{3}$ content of $1.6 \mu \mathrm{g} / 100 \mathrm{~g}$; equilibrium was probably not reached as the content 5 days after ceased exposure was $1.7 \mu \mathrm{g} / 100 \mathrm{~g}$ (Argyraki, 2017).

\subsection{Effect of exposing the legs of hens to UVB}

Schutkowski et al. (2013) exposed the legs of hens, supplemented with $75 \mu \mathrm{g}$ vitamin $\mathrm{D}_{3} / \mathrm{kg}$ feed, to a dose of $8208 \mathrm{~J} / \mathrm{m}^{2} /$ day for 4 weeks; the reported content of vitamin $\mathrm{D}_{3}$ and $25(\mathrm{OH}) \mathrm{D}_{3}$ is $4,9 \mu \mathrm{g} / 100 \mathrm{~g}$ and $0,57 \mu \mathrm{g} / 100 \mathrm{~g}$ respectively. Kühn et al. (2015) irradiated the legs of hens to 7 different doses of UVB between 0-13680 J/m²/day during 4 weeks and showed that vitamin $\mathrm{D}_{3}$ in the eggs increased non-linearly with dose and at the highest dose the content was $4.5 \mu \mathrm{g} / 100 \mathrm{~g}$ and it was almost at equilibrium. $25(\mathrm{OH}) \mathrm{D}_{3}$ content of eggs also increased non-linearly but did not increase beyond a dose of $5472 \mathrm{~J} / \mathrm{m}^{2} /$ day where equilibrium was reached with a content of $0.6 \mu \mathrm{g} / 100 \mathrm{~g}$.

\section{Vitamin D enhancement of liquid egg products by direct exposure to UVB}

Egg yolk contain around $140 \mu \mathrm{g}$ 7-DHC per 100 g (Kühn, Schutkowski, Kluge, Hirche, \& Stangl, 2014); therefore there is a potential that egg yolk can be enhanced with vitamin D by exposing it directly to UVB. In a small pilot study, described in Argyraki (2017), we exposed egg yolk and whole egg mix to UVB light using the UVB-LED with a central wavelength of $296 \mathrm{~nm}$ described in Barnkob et al. (2016). Layers of 3-4 mm liquid egg were placed in small weigh boats and then exposed to a dose of $3000 \mathrm{~J} / \mathrm{m}^{2}$; the exposure time was approximately $3.5 \mathrm{~min}$. In whole egg the vitamin $\mathrm{D}_{3}$ content increased from 1.1 to $4.3 \mu \mathrm{g} / 100 \mathrm{~g}$ and in egg yolk the content increased from 5.2 to $18.9 \mu \mathrm{g} / 100 \mathrm{~g}$; close to a factor of 4 in increased content. By adjusting the UVB dose it would be possible to tailor the vitamin D content in liquid egg products. The 
penetration depth of UVB at $296 \mathrm{~nm}$ is $0.01-0.08 \mathrm{~mm}$ (Argyraki, 2017) therefore any practical application would have to be on a very thin film or in a dynamic treatment (e.g. stirring).

Dynamic treatment of liquid egg products with an UVC dose of $42000 \mathrm{~J} / \mathrm{m}^{2}$ obtained in 30 minutes has the same disinfectant properties as heat pasteurization but with only minor changes to the rheological properties (de Souza \& Fernández, 2013). It has been shown that UVB is more effective than UVC in inactivating the bacteria Pseudomonas aeruginosa in a trial where the exact same UV-LED as used for UVB exposure of hens in (Argyraki, 2017) was used; a dose of $10,000 \mathrm{~J} / \mathrm{m}^{2}$ left no viable colonies, and the exposure time was less than 12 minutes (Argyraki, Markvart, Bjørndal, Bjarnsholt, \& Petersen, 2017). Thereby, there is potential that a dynamic treatment with UVB, alone or in combination with UVC could produce both safe and vitamin D enriched liquid egg products (yolk and whole egg mix).

\section{Discussion on future trends}

In Denmark the average intake of eggs per person per day is $25 \mathrm{~g}$ (Pedersen et al., 2015), in Ireland it is $16 \mathrm{~g}$ (O’Mahony et al., 2011). $10 \%$ of males in Denmark ingest more than $55 \mathrm{~g}$ per day (Pedersen et al., 2015).

How effective $25(\mathrm{OH}) \mathrm{D}_{3}$ is compared to vitamin $\mathrm{D}_{3}$ in increasing serum $25(\mathrm{OH}) \mathrm{D}_{3}$ depends on the dose of $25(\mathrm{OH}) \mathrm{D}_{3}$. The factor between the efficiencies is 1.04 at $5 \mu \mathrm{g} /$ day, $1.5-5.5$ at doses below $25 \mu \mathrm{g} /$ day and 8 at doses above $50 \mu \mathrm{g} /$ day (reviewed by Quesada-Gomez \& Bouillon (2018), (Jakobsen et al., 2018)). The daily intake of $25(\mathrm{OH}) \mathrm{D}_{3}$ from food is assumed to be less than $5 \mu \mathrm{g} / \mathrm{day}$, for this reason we have used factor 1 when calculating the total vitamin D content. Cooking loss and bioavailability have not been included in the calculation of the average intake of vitamin D from eggs.

According to the findings in Section 7 the average total vitamin D content in commercial eggs is 2 $\mu \mathrm{g} / 100 \mathrm{~g}$ (using factor 1 for $25(\mathrm{OH}) \mathrm{D}_{3}$, see above). The maximum obtainable total vitamin $\mathrm{D}$ content in eggs from hens exposed to UVB, directed at the legs (in cages), is $5.1 \mu \mathrm{g} / 100 \mathrm{~g}$ (see Section 9.3). If eggs in 
person would increase with $0.8 \mu \mathrm{g}$ and $0.5 \mu \mathrm{g}$, respectively (the actual intake will be lower as cooking loss was not included in the calculations). However, implementing UVB-lamps directed at the feet of the hens in a barn will be a challenging task. If placed near the floor the lamps will get dirty and a vast amount of cleaning will be required. In addition, only the hens nearby the lamp will be exposed and the dose each hen receives will be hard to control. If UVB-treatment is to be implemented in barn egg production facilities it will be necessary to develop solutions where the hens are irradiated from above to ensure even exposure and minimisation of costs for both maintenance and cleaning.

The gap between the recommended and the actual vitamin D intake is 3-17 $\mu \mathrm{g} /$ day/person and it therefore might be desirable to increase the vitamin D content of eggs further than what is possible with UVB exposure. There is an inter-trial linear relationship between the vitamin $\mathrm{D}_{3}$ content in the feed and the content of vitamin $D_{3}$ in the egg (see section 8.1) and within the linear range the highest content is $20 \mu \mathrm{g} / 100$ $\mathrm{g}$ which is achieved with a vitamin $\mathrm{D}_{3}$ content of $617.5 \mu \mathrm{g} / \mathrm{kg}$ feed. This level is well within the reported safe level for laying hens (Mattila et al., 2003, 2004; Persia et al., 2013). Feeding vitamin $\mathrm{D}_{3}$ will also increase the content of $25(\mathrm{OH}) \mathrm{D}_{3}$ in the egg, however the relationship between vitamin $\mathrm{D}_{3}$ in feed and the $25(\mathrm{OH}) \mathrm{D}_{3}$ is most likely logarithmic with a maximum around $1 \mu \mathrm{g} / 100 \mathrm{~g}$ (see Figure 2). The total vitamin D content in eggs from hens supplemented with $617.5 \mu \mathrm{g} / \mathrm{kg}$ feed would be $21 \mu \mathrm{g} / 100 \mathrm{~g}$; such a level would increase of the daily average intake from eggs per person with $4.8 \mu \mathrm{g}$ in Denmark and $3.0 \mu \mathrm{g}$ in Ireland. Although this content might be too high, for a single source of vitamin $\mathrm{D}$, it illustrates that it is possible to design the vitamin $\mathrm{D}_{3}$ content to any desired level through feed.

The use of $25(\mathrm{OH}) \mathrm{D}_{3}$ in feed was legalised in 2009 in Europe, and trials have shown that $25(\mathrm{OH}) \mathrm{D}_{3}$ content of eggs will increase when $25(\mathrm{OH}) \mathrm{D}_{3}$ is added to the feed; however, there is not the same linear inter-trial tendency as observed for vitamin $\mathrm{D}_{3}$, and the dose-response is a factor 3 less compared to vitamin $D_{3}$. Also, $25(\mathrm{OH}) \mathrm{D}_{3}$ is more toxic to hens than vitamin $\mathrm{D}_{3}$ as $413 \mu \mathrm{g} / \mathrm{kg}$ feed is on the margin of being toxic (Terry et al., 1999) whereas no negative effects of vitamin $D_{3}$ has been observed with a dose of $2555 \mu \mathrm{g} / \mathrm{kg}$ feed (Yao et al., 2013). 
Feeding a combination of $250 \mu \mathrm{g} / \mathrm{kg}$ feed of vitamin $\mathrm{D}_{3}$ and $69 \mu \mathrm{g} / \mathrm{kg}$ feed of $25(\mathrm{OH}) \mathrm{D}_{3}$ gives a total vitamin D content of $12.9 \mu \mathrm{g} / 100 \mathrm{~g}$ (Browning \& Cowieson, 2014). To obtain the same level using vitamin $\mathrm{D}_{3}$ alone would require approximately $378 \mu \mathrm{g} / \mathrm{kg}$ feed.

In order to increase the content of vitamin D in eggs through feed the European legislation has to be changed, as the current limit is $80 \mu \mathrm{g}$ vitamin D/kg feed. Fortunately, these limits are not set in stone; according to the procedure described in Regulation (EC) No 1831/2003 one can send an application with new information to the European Commission (using the application form found in Commission Regulation (EC) No 492/2008) the Commission shall send it to EFSA who shall provide a new opinion. If the opinion is positive it will most likely result in a draft Regulation made by the Standing Committee on Plant, Animals, Food and Feed (PAFF committee - section animal nutrition), on behalf of the European Commission, who will also decide if the draft Regulation should eventually be put into force. The Norwegian Food Safety Authority (NFSA) applied for increasing the maximum limit 20 times, from $75 \mu \mathrm{g} / \mathrm{kg}$ feed to $1.5 \mathrm{mg} / \mathrm{kg}$ feed for salmonids and received a positive opinion from EFSA (EFSA, 2017, 2019). The opinion was discussed at a PAFF committee meeting in April 2019 and was voted for with a favourable opinion (Standing Committee on Plant, Animals, 2019) ; and in May 2019 a feeding level of $60000 \mathrm{IU} / \mathrm{kg}$ ( 1.5 mg/kg feed) for salmonids was implemented into the existing regulation (Regulation (EU) 2019/849).

\section{Conclusion}

If choosing between feed and UVB exposure for natural enhancement of eggs with vitamin D, increasing the vitamin $\mathrm{D}_{3}$ in the feed seems to give the most predictable and cost-effective results as only the feed has to be changed. In order to use this option in the EU an application must to be submitted to, and approved by, the European Commission; for salmonids the maximum limit was in 2019 increased 20 times upon such application.

A third option is to expose liquid egg products directly to UVB. With this method the vitamin D content can be tailored by adjusting the dose, and in addition the bacterial load is reduced due to the dual effect of 
400 UVB; however further research and development of equipment is needed for this to be implemented and 401 approved as a novel food. not-for-profit sectors.

406

\section{References}

408

Argyraki, A. (2017). New light Sources for Biomedical Applications. Technical University of Denmark applications(4c1e9ea9-6508-4134-ba60-00fd50d1f00d).html

Argyraki, A., Markvart, M., Bjørndal, L., Bjarnsholt, T., \& Petersen, P. M. (2017). Inactivation of Pseudomonas aeruginosa biofilm after ultraviolet light-emitting diode treatment: a comparative study between ultraviolet C and ultraviolet B. Journal of Biomedical Optics, 22(6), 065004. http://doi.org/10.1117/1.jbo.22.6.065004

Barnkob, L. L., Argyraki, A., Petersen, P. M. P. M., \& Jakobsen, J. (2016). Investigation of the effect of UVLED exposure conditions on the production of vitamin D in pig skin. Food Chemistry, 212, 386-391. http://doi.org/10.1016/j.foodchem.2016.05.155

BASF. (1998). Vitamin Supplementation Rates for U.S. Commercial Poultry, Swine and Dairy Cattle, 1997. KC 9305. 2nd Revised Edition. Retrieved from http://www.advit.co.za/downloads/BASF KC 9305.pdf 
as affected by the ration and management of the layers. Journal of Biological Chemistry, 72, 695-706.

425

426

427

428

429

430

431

432

433

434

435

436

437

438

439

440

441

442

Bilodeau, L., Dufresne, G., Deeks, J., Clément, G., Bertrand, J., Turcotte, S., ... Fouquet, a. (2011). Determination of vitamin D3 and 25-hydroxyvitamin D3 in foodstuffs by HPLC UV-DAD and LCMS/MS. Journal of Food Composition and Analysis, 24(3), 441-448. http://doi.org/10.1016/j.jfca.2010.08.002

Black, L. J., Seamans, K. M., Cashman, K. D., \& Kiely, M. (2012). An Updated Systematic Review and Meta-Analysis of the Efficacy of Vitamin D Food Fortification. Journal of Nutrition, 142(6), 11021108. http://doi.org/10.3945/jn.112.158014

Borel, P., Caillaud, D., \& Cano, N. J. (2015). Vitamin D Bioavailability: State of the Art. Critical Reviews in Food Science and Nutrition, 55(9), 1193-1205. http://doi.org/10.1080/10408398.2012.688897

Branion, H. D., Drake, T. G., \& Tisdall, F. F. (1935). The vitamin D content of egg yolk. Canadian Medical Association Journal, 32(1), 9-12.

Browning, L. C., \& Cowieson, A. J. (2014). Vitamin D fortification of eggs for human health. Journal of the Science of Food and Agriculture, 94(7), 1389-96. http://doi.org/10.1002/jsfa.6425

Carson, J. R., \& Beall, G. (1955). Absence of Response by Breeder Hens to Ultraviolet Energy. Poultry Science, 34(2), 256-262.

Cashman, K. D. (2015). Vitamin D: dietary requirements and food fortification as a means of helping achieve adequate vitamin D status. Journal of Steroid Biochemistry and Molecular Biology, 148, 1926. http://doi.org/10.1016/j.jsbmb.2015.01.023

Cashman, K. D., Dowling, K. G., Gonzalez-Gross, M., Valtue, J., Henauw, S. De, Moreno, L., ... Kiely, M. (2016). Vitamin D deficiency in Europe: pandemic? American Journal of Clinical Nutrition, 103, 1033-1044. http://doi.org/10.3945/ajcn.115.120873

Cashman, K. D., \& Kiely, M. (2016). Tackling inadequate vitamin D intakes within the population: 
fortification of dairy products with vitamin D may not be enough. Endocrine, 51(1), 38-46. http://doi.org/10.1007/s12020-015-0711-x

Chiang, Y. H., Hwang, S. I., \& Holick, M. F. (1996). Influence of different time of ultraviolet irradiation on performance and vitamin D-3 metabolism in laying hens. Korean Journal of Animal Nutrition and Feedstuffs, 20(6), 497-508.

Chiang, Y. H., Hwang, S. I., \& Holick, M. F. (1997). Effect of vitamin $\mathrm{D}_{3}$ oral dose or ultraviolet irradiation on yolk vitamin D3, plasma minerals, eggshell thickness and intensity in laying hens. Korean Journal of Animal Nutrition and Feedstuffs, 21(6), 475-488.

Chirkin, V. a., Karpov, S. I., Selemenev, V. F., \& Shumskiy, N. I. (2013). Determination of fat-soluble vitamins in foods, vitamin and mineral formulations, feed premixes, and blood serum by reversedphase HPLC. Journal of Analytical Chemistry, 68(8), 748-753. http://doi.org/10.1134/S1061934813080042

Christakos, S., Dhawan, P., Verstuyf, A., Verlinden, L., \& Carmeliet, G. (2016). Vitamin D: Metabolism, Molecular Mechanism of Action, and Pleiotropic Effects. Physiol Rev, 96, 365-408. http://doi.org/10.1152/physrev.00014.2015.-1,25-Dihydrox

de Souza, P. M., \& Fernández, A. (2013). Rheological properties and protein quality of UV-C processed liquid egg products. Food Hydrocolloids, 31(1), 127-134. http://doi.org/10.1016/j.foodhyd.2012.05.013

DeVaney, G. M., Munsell, H. E., \& Titus, H. W. (1933). Effect of Sources of Vitamin D on Storage of the Antirachitic Factor in the Egg. Poultry Science, 12(4), 215-222. http://doi.org/10.3382/ps.0120215

Dimartino, G. (2009). Simultaneous determination of cholecalciferol (vitamin D3) and ergocalciferol (vitamin D2) in foods by selected reaction monitoring. J. AOAC International., 92, 511-517. 
DTU Library. (n.d.). DTU Findit (DTU version): About DTU Findit. Retrieved April 3, 2019, from http://libguides.dtu.dk/c.php?g=654792\&p=4600996

Duffy, S. K., Rajauria, G., Clarke, L. C., Kelly, A. K., Cashman, K. D., \& O’Doherty, J. V. (2017). The potential of cholecalciferol and 25-hydroxyvitamin D3 enriched diets in laying hens, to improve egg vitamin D content and antioxidant availability. Innovative Food Science \& Emerging Technologies. http://doi.org/10.1016/j.ifset.2017.07.007

Dunlop, E., Cunningham, J., Sherriff, J., Lucas, R., Greenfield, H., Arcot, J., ... Black, L. J. (2017). Vitamin D3 and 25-Hydroxyvitamin D3 Content of Retail White Fish and Eggs in Australia. Nutrients, 9(7), 647. http://doi.org/10.3390/nu9070647

Edwards, H. M. (2003). Effects of u.v. irradiation of very young chickens on growth and bone development. British Journal of Nutrition, 90, 151. http://doi.org/10.1079/BJN2003860

EFSA. (2005). Opinion of the Scientific Panel on additives and products or substances used in animal feed (FEEDAP) on the evaluation of safety and efficacy of "Hy•D" (calcifediol), based on 25hydroxylcholecalciferol/25-hydroxy-pre-cholecalciferol, as feed additive in. EFSA Journal, 3(7), 224. http://doi.org/10.2903/j.efsa.2005.224

EFSA. (2014). Scientific Opinion on the safety and efficacy of vitamin D3 (cholecalciferol) as a feed additive for all animal species or categories based on a dossier submitted by Lohmann Animal Health GmbH. EFSA Journal, 12(2), 3568. http://doi.org/10.2903/j.efsa.2014.3568

EFSA. (2017). Safety of vitamin $\mathrm{D}_{3}$ addition to feedingstuffs for fish. EFSA Journal, 15(3). http://doi.org/10.2903/j.efsa.2017.4713

EFSA. (2019). Safety for the environment of vitamin $\mathrm{D}_{3}$ for salmonids. EFSA Journal, 17(1). http://doi.org/10.2903/j.efsa.2019.5540 
494

495

496

497

498

Farrell, F. (1924). Relation of vitamin content of feed and of the use of light to immunity to roup and the production and hatchability of eggs. Director's Report 1922-1924 for the Biennium. Agricultiural Experiment Station, Kansas State Agricultural College, Manhatten, Kansas, 113-116.

Francis G. McDonald, \& Massengale, O. N. (1932). The antiricketic potenct of eggs from hens receiving massive doses of activated ergosterol. J. Biol. Chem., 99(1), 79-83.

Fraser, D. R., \& Emtage, J. S. (1976). Vitamin D in the Avian Egg - its molecular identity and mechanism of incorporation into yolk. Biochem J, 160, 671-682.

Gray, J. (2018). British eggs: Back on the menu for all. Nutrition Bulletin, 43(1), 85-92. http://doi.org/10.1111/nbu.12310

Guerrant, N. B., Kohler, E., Hunter, J. E., \& Murphy, R. R. (1935). The Relationship of the Vitamin D Intake of the Hen to the Antirachitic Potency of the Eggs Produced. The Journal of Nutrition, 10(2), 167-178.

Guo, J., Kliem, K. E., Lovegrove, J. A., \& Givens, D. I. (2017). Effect of production system, supermarket and purchase date on the vitamin D content of eggs at retail. Food Chemistry, 221, 1021-1025. http://doi.org/10.1016/j.foodchem.2016.11.060

Hart, E., Steenbock, H., Lepkovsky, S., Kletzien, S. W. F., Halpin, J. G., \& Johnson, O. N. (1925). The nutritional requirement of the chicken. V. The influence of ultra-violet light on the production, hatchability, and fertility of the egg. Journal of Biological Chemistry, 65(3), 579-595.

Hayes, A., Duffy, S., OGrady, M., Jakobsen, J., Galvin, K., Teahan-Dillon, J., .. Cashman, K. D. (2016). Vitamin D-enhanced eggs are protective of wintertime serum 25-hydroxyvitamin D in a randomized controlled trial of adults. American Journal of Clinical Nutrition, 104(3), 629-637. http://doi.org/10.3945/ajen.116.132530 
Hendricks, W. (1931). Effects of cod-liver oil and ultra-violet irradiation, as influenced by oyster shell, in the diet of confined laying hens. Journal of Agricultural Research, 43, 0517-0535.

Holick, M. F. (2017). The vitamin D deficiency pandemic: Approaches for diagnosis, treatment and prevention. Rev Endocr Metab Disord, 18(2), 153-165. http://doi.org/10.1007/s11154-017-9424-1

Holick, M. F., MacLaughlin, J. A., Clark, M. B., Holic, S. A., Potts, T. J., Anderson, R. R., ... Elias, P. (1980). Photosynthesis of Previtamin $\mathrm{D}_{3}$ in Human Skin And the Physiologic Consequences. Science, 210(4466), 203-205. http://doi.org/10.1126/science.6251551

Holvik, K., Madar, A. A., Meyer, H. E., Lofthus, C. M., \& Stene, L. C. (2007). A randomised comparison of increase in serum 25-hydroxyvitamin D concentration after 4 weeks of daily oral intake of $10 \mu \mathrm{g}$ cholecalciferol from multivitamin tablets or fish oil capsules in healthy young adults. British Journal of Nutrition, 98(3), 620-625. http://doi.org/10.1017/S000711450773074X

Hughes, J., \& Payne, L. (1924). Influence of ultra-violet light on young laying hens. Science, 60(1563), 54950.

Hughes, J., Payne, L., Titus, R., \& Moore, J. (1925). The relation between the amount of ultraviolet light received by hens and the amount of antirachitic vitamin in the eggs produced. Journal of Biological Chemistry, 66(2), 595-600.

Indyk, H. \& Wollard, D. (1985). The determination of vitamin D in supplemented milk powders by HPLC II. Incorporation of internal standard. New Zealand Journalof Dariy Science and Technology, 20, 19-29.

Institute of Medicine. (2011). Dietary Reference Intakes for Vitamin D and Calcium. Washington DC: The National Academies Press. http://doi.org/10.17226/13050

Jääskeläinen, T., Itkonen, S. T., Lundqvist, A., Erkkola, M., Koskela, T., Lakkala, K., ... Lamberg-Allardt, C. (2017). The positive impact of general Vitamin D food fortification policy on Vitamin D status in a representative adult Finnish population: Evidence from an 11-y follow-up based on standardized 25- 
hydroxyVitamin D data. American Journal of Clinical Nutrition, 105(6), 1512-1520. http://doi.org/10.3945/ajcn.116.151415

Jackson, P. A., Shelton, C. J., \& Frier, P. J. (1982). High-performance liquid chromatographic determination of vitamin D3 in foods with particular reference to eggs. The Analyst, 107(1280), 1363-1369. http://doi.org/10.1039/AN9820701363

Jakobsen, J., Andersen, E., Christensen, T., Andersen, R., Bügel, S., Jakobsen, J., ... Bügel, S. (2018). Vitamin D Vitamers Affect Vitamin D Status Differently in Young Healthy Males. Nutrients, 10(1), 12. http://doi.org/10.3390/nu10010012

Jakobsen, J., \& Knuthsen, P. (2014). Stability of vitamin D in foodstuffs during cooking. Food Chemistry, 148, 170-175. http://doi.org/10.1016/j.foodchem.2013.10.043

Kawazoe, T., Yuasa, K., Noguchi, K., Yamazaki, M., \& Ando, M. (1996). Effect of different sources of vitamin D on transfer of vitamin D to egg yolk. Nippon Shokuhin Kagaku Kogaku Kaishi, 43(4), 444450. http://doi.org/https://doi.org/10.3136/nskkk.43.444

Kawazoe, T., Yuasa, K., Yamazaki, M., \& Ando, M. (1994). Production of Vitamin D-fortified eggs by feeding vitamin D2-fortified shiitake. Nippon Shokuhin Kagaku Kogaku Kaishi, 41(12), 891-896. http://doi.org/https://doi.org/10.3136/nskkk1962.41.891

Keegan, R. J. H., Lu, Z., Bogusz, J. M., Williams, J. E., \& Holick, M. F. (2013). Photobiology of vitamin D in mushrooms and its bioavailability in humans. Dermato-Endocrinology, 5(1), 165-176. http://doi.org/10.4161/derm.23321

Kiely, M., \& Black, L. J. (2012). Dietary strategies to maintain adequacy of circulating 25-Hydroxyvitamin D concentrations. Scandinavian Journal of Clinical and Laboratory, 72, 14-23. http://doi.org/10.3109/00365513.2012.681893

Koch, E. M., \& Koch, F. C. (1941). The Provitamin D of the Covering Tissues of Chickens. Poultry Science, 
Koshy, K. T., \& Van Der Slik, A. L. (1979). High-performance liquid chromatographic method for the determination of 25-hydroxycholecalciferol in chicken egg yolks. Journal of Agricultural and Food Chemistry, 27(1), 180-183. http://doi.org/10.1021/jf60221a033

Kühn, J., Schutkowski, A., Hirche, F., Baur, A. C., Mielenz, N., \& Stangl, G. I. (2015). Non-linear increase of vitamin D content in eggs from chicks treated with increasing exposure times of ultraviolet light. The Journal of Steroid Biochemistry and Molecular Biology, 148, 7-13. http://doi.org/10.1016/j.jsbmb.2014.10.015

Kühn, J., Schutkowski, A., Kluge, H., Hirche, F., \& Stangl, G. I. (2014). Free-range farming: A natural alternative to produce vitamin D-enriched eggs. Nutrition, 30(4), 481-484. http://doi.org/10.1016/j.nut.2013.10.002

Lehtonen-Veromaa, M., Möttönen, T., Leino, A., Heinonen, O. J., Rautava, E., \& Viikari, J. (2008). Prospective study on food fortification with vitamin D among adolescent females in Finland: minor effects. The British Journal of Nutrition, 100(2), 418-23. http://doi.org/10.1017/S0007114508894469

Lietzow, J., Kluge, H., Brandsch, C., Seeburg, N., Hirche, F., Glomb, M., \& Stangl, G. I. (2012). Effect of short-term UVB exposure on vitamin D concentration of eggs and vitamin D status of laying hens. Journal of Agricultural and Food Chemistry, 60(3), 799-804. http://doi.org/10.1021/jf204273n

Liu, J., Greenfield, H., \& Fraser, D. R. (2014). An exploratory study of the content of vitamin D compounds in selected samples of Australian eggs. Nutrition \& Dietetics, 71(1), 46-50. http://doi.org/10.1111/1747-0080.12056

MacLaughlin, J. A., Anderson, R. R., \& Holick, M. F. (1982). Spectral character of sunlight modulates photosynthesis of previtamin $\mathrm{D}_{3}$ and its photoisomers in human skin. Science, 216(4549), 1001-1003. http://doi.org/10.1126/science.6281884 
Mattila, P., Piironen, V., Bäckman, C., Asunmaa, A., Uusi-rauva, E., \& Koivistoinen, P. (1992). Determination of Vitamin D3 in Egg Yolk by High-Performance Liquid Chromatography with Diode Array Detection. Journal of Food Composition and Analysis, 5, 281-290. http://doi.org/https://doi.org/10.1016/0889-1575(92)90062-O

Mattila, P., Piironen, V., Uusi-rauva, E., \& Koivistoinen, P. (1993). Determination of 25Hydroxycholecalciferol Content in Egg Yolk by HPLC. Journal of Food Composition and Analysis, 6, 250-255. http://doi.org/https://doi.org/10.1006/jfca.1993.1027

Mattila, H., Piironen, V.I., Uusi-Rauva, E.J. \& Koivistoinen, P.E. (1995). Contents of cholecalciferol, ergocalciferol, and their 25-hydroxylated metabolites in milk products and raw meat and liver as determined by HPLC. Journal of Agricultural and Food Chemistry, 43, 2394-2399.

Mattila, P., Lehikoinen, K., Kiiskinen, T., \& Piironen, V. (1999). Cholecalciferol and 25hydroxycholecalciferol content of chicken egg yolk as affected by the cholecalciferol content of feed. Journal of Agricultural and Food Chemistry, 47(10), 4089-4092. http://doi.org/10.1021/jf990183c

Mattila, P., Rokka, T., Könkö, K., Valaja, J., Rossow, L., \& Ryhänen, E.-L. (2003). Effect of cholecalciferolenriched hen feed on egg quality. Journal of Agricultural and Food Chemistry, 51(1), 283-7. http://doi.org/10.1021/jf020743z

Mattila, P., Ronkainen, R., Lehikoinen, K., \& Piironen, V. (1999). Effect of household cooking on the vitamin D content in fish, eggs, and wild mushrooms. Journal of Food Composition and Analysis, 12, 153-160. http://doi.org/https://doi.org/10.1006/jfca.1999.0828

Mattila, P., Valaja, J., Rossow, L., Venäläinen, E., \& Tupasela, T. (2004). Effect of vitamin D2- and D3enriched diets on egg vitamin D content, production, and bird condition during an entire production period. Poultry Science, 83(3), 433-40. http://doi.org/10.1093/ps/83.3.433

Mattila, P., Valkonen, E., \& Valaja, J. (2011). Effect of different vitamin D supplementations in poultry feed on vitamin D content of eggs and chicken meat. Journal of Agricultural and Food Chemistry, 59(15), 
609

610

611

612

613

614

615

616

617

618

619

620

621

622

623

624

625

626

627

628

629

630

631

8298-303. http://doi.org/10.1021/jf2012634

Maughan, G. H., \& Maughan, E. (1933). The vitamin D potency of egg yolk from irradiated hens. Science, 77(1990), 198. http://doi.org/10.1126/science.77.1990.198

Mejborn, H., Jacobsen, S. M., \& Trolle, E. (2011). Æg i kosten og betydningen for sundhed og sygdom. Søborg. Retrieved from http://www.food.dtu.dk/english/publications/nutrition

Nordic Council of Ministers. (2012). Nordic Nutrition Recommendations 2012 : Integrating nutrition and physical activity. Nordisk Ministerråd.

O’Mahony, L., Stepien, M., Gibney, M. J., Nugent, A. P., \& Brennan, L. (2011). The potential role of vitamin D enhanced foods in improving vitamin D status. Nutrients, 3(12), 1023-41. http://doi.org/doi:10.3390/nu3121023

O’Neill, C., Kazantzidis, A., Ryan, M., Barber, N., Sempos, C., Durazo-Arvizu, R., ... Cashman, K. D. (2016). Seasonal Changes in Vitamin D-Effective UVB Availability in Europe and Associations with Population Serum 25-Hydroxyvitamin D. Nutrients, 8(9), 533. http://doi.org/10.3390/nu8090533

Ovesen, L., Brot, C., \& Jakobsen, J. (2003). Food contents and biological activity of 25-hydroxyvitamin D: A vitamin D metabolite to be reckoned with? Annals of Nutrition and Metabolism, 47(3-4), 107-113.

Park, S. W., Namkung, H., Ahn, H. J., \& Paik, I. K. (2005). Enrichment of Vitamins $D_{3}$, K and Iron in Eggs of Laying Hens. Asian-Australasian Journal of Animal Sciences, 18(2), 226-229.

Pedersen, A., Christensen, T., Matthiesen, J., Knudsen, V. B., Rosenlund-Sørensen, M., Biltoft-Jensen, A., ... Fagt, S. (2015). Dietary habits in Denmark 2011-2013. Main results. Søborg. Retrieved from http://www.food.dtu.dk/english/Publications/Nutrition/Danish-National-Survey-of-Dietary-Habits-andPhysical-Activity

Persia, M. E., Higgins, M., Wang, T., Trample, D., \& Bobeck, E. a. (2013). Effects of long-term supplementation of laying hens with high concentrations of cholecalciferol on performance and egg 
quality. Poultry Science, 92(11), 2930-7. http://doi.org/10.3382/ps.2013-03243

Plaimast, H., Kijparkorn, S., \& Ittitanawong, P. (2015). Effects of vitamin $\mathrm{D}_{3}$ and calcium on productive performance, egg quality and vitamin $\mathrm{D}_{3}$ content in egg of second production cycle hens. Thai Journal of Veterinary Medicine, 45(2), 189-195. http://doi.org/10.1590/S1516-635X2011000300005

PHE. (2015). McCance and Widdowson's 'composition of foods integrated dataset' on the nutrient content of the UK food supply. Retrieved from https://www.gov.uk/government/publications/composition-offoods-integrated-dataset-cofid

Quesada-Gomez, J. M., \& Bouillon, R. (2018). Is calcifediol better than cholecalciferol for vitamin D supplementation? Osteoporosis International, 29(8), 1697-1711. http://doi.org/10.1007/s00198-018$4520-y$

Reboul, E. (2015). Intestinal absorption of vitamin D: from the meal to the enterocyte. Food \& Function, 6, 356-362. http://doi.org/10.1039/c4fo00579a

Schutkowski, A., Krämer, J., Kluge, H., Hirche, F., Krombholz, A., Theumer, T., \& Stangl, G. I. (2013). UVB exposure of farm animals: study on a food-based strategy to bridge the gap between current vitamin D intakes and dietary targets. PloS One, 8(7), e69418.

Sivell, L. M., Wenlock, R. W., \& Jackson, P. A. (1982). Determination of vitamin D and retinoid activity in eggs by HPLC. Human Nutrition. Applied Nutrition, 36(6), 430-7.

Standing Committee on Plant, Animals, F. and F. S. A. N. (2019). Standing Committee on Plants, Animals, Food and Feed Section Animal Nutrition. 09-11 April 2019. Agenda. Retrieved from https://ec.europa.eu/food/animals/committees/sc_animal-nutrition_en

Sunde, M. L., Turk, C. M. \& DeLuca, H. F. (1978). The Essentiality of Vitamin D Metabolites for Embryonic Chick Development. Science, New Series, 200, 1067-1069

Światkiewicz, S., Arczewska-Wlosek, A., Bederska-Lojewska, D., \& Józefiak, D. (2017). Efficacy of dietary 
655

vitamin D and its metabolites in poultry - review and implications of the recent studies. World's Poultry Science Journal, 73(01), 57-68. http://doi.org/10.1017/S0043933916001057

Takeuchi, A., Okano, T., Teraoka, S., Murakami, Y., \& Kobayashi, T. (1984). High-performance Liquid Chromatographic Determination of vitamin D in Foods, Feeds, and Pharmaceuticals by Succesive Use og Reversed-Phase and Straight-Phase Columns. Journal of Nutritional Science and Vitaminology, $30(1), 11-25$.

Terry, M., Lanenga, M., McNaughton, J. L., \& Stark, L. E. (1999). Safety of 25-hydroxyvitamin $\mathrm{D}_{3}$ as a source of vitamin $\mathrm{D}_{3}$ in layer poultry feed. Veterinary and Human Toxicology, 41(5), 312-6.

Tian, X. Q., Chen, T. C., Lu, Z., Shau, Q., \& Holick, M. F. (1994). Characterization of the translocation process of vitamin D3 from the skin into the circulation. Endocrinology, 135(2), 655-661.

Torbergsen, A. C., Watne, L. O., Wyller, T. B., Frihagen, F., Strømsøe, K., Bøhmer, T., \& Mowe, M. (2015). Vitamin $\mathrm{K} 1$ and 25(OH)D are independently and synergistically associated with a risk for hip fracture in an elderly population: A case control study. Clinical Nutrition, 34(1), 101-106. http://doi.org/10.1016/j.clnu.2014.01.016

USDA. (2019). FoodData Central. Eggs, grade A,large, egg whole (foundation, 748967). Retrieved May 4, 2020, from https://fdc.nal.usda.gov/index.html

Uva, B., Mandich, A., \& Vallarino, M. (1983). The site of 7-dehydrocholesterol ultraviolet photolysis in domestic fowls. Acta Histochemica, 73(2), 175-180.

Webb, A. R. (2006). Who, what, where and when-influences on cutaneous vitamin D synthesis. Progress in Biophysics and Molecular Biology, 92(1), 17-25. http://doi.org/10.1016/j.pbiomolbio.2006.02.004

Webb, A. R., DeCosta, B. R., \& Holick, M. F. (1989). Sunlight regulates the cutaneous production of vitamin D3 by causing its photodegradation. Journal of Clinical Endocrinology and Metabolism, 68(5), 882-887. http://doi.org/10.1210/jcem-68-5-882 
678 Webb, A. R., Kline, L., \& Holick, M. F. (1988). Influence of season and latitude on the cutaneous synthesis 679 of vitamin D3: exposure to winter sunlight in Boston and Edmonton will not promote vitamin $\mathrm{D}_{3}$ 680 synthesis in human skin. The Journal of Clinical Endocrinology and Metabolism, 67(2), 373-8.

681 Whiting, S. J., Green, T. J., \& Calvo, M. S. (2007). Vitamin D intakes in North America and Asia-Pacific 682 countries are not sufficient to prevent vitamin D insufficiency. The Journal of Steroid Biochemistry and 683 Molecular Biology, 103(3-5), 626-30. http://doi.org/10.1016/j.jsbmb.2006.12.067

684 Yao, L., Wang, T., Persia, M., Horst, R. L., \& Higgins, M. (2013). Effects of vitamin $D_{3}$-enriched diet on 685 egg yolk vitamin D3 content and yolk quality. Journal of Food Science, 78(2), C178-83.

686 http://doi.org/10.1111/1750-3841.12032

687 Zang, H., Zhang, K., Ding, X., Bai, S., Hernández, J. M., \& Yao, B. (2011). Effects of Different Dietary 688 Vitamin Combinations on the Egg Quality and Vitamin deposition in the Whole Egg of Laying Hens. 689 Brazilian Journal of Poultry Science, 13(3), 189-196. http://doi.org/10.1590/S1516$690 \quad 635 \times 2011000300005$

691 692 


\section{Figure captions}

694 Figure 1. Vitamin $\mathrm{D}_{3}$ content in eggs as a function of vitamin $\mathrm{D}_{3}$ content in feed

695

696 Figure 2. $25(\mathrm{OH}) \mathrm{D}_{3}$ content in eggs as a function of vitamin $\mathrm{D}_{3}$ content in feed. Full black line is exponential

697 regression while dotted line shows linear regression of the data.

698

699 Figure 3. $25(\mathrm{OH}) \mathrm{D}_{3}$ content in eggs as a function of $25(\mathrm{OH}) \mathrm{D}_{3}$ content in feed.

700

701 Figure 4. $25(\mathrm{OH}) \mathrm{D}_{3}$ content in eggs from hens fed $25(\mathrm{OH}) \mathrm{D}_{3}$ in combination with vitamin $\mathrm{D}_{3}$. [1] Mattila et al. (2011);

702 [2] Browning \& Cowieson (2014); [3] Duffy et al. (2017). 
Table 1. Average content of vitamin $\mathrm{D}_{3}$ and $25(\mathrm{OH}) \mathrm{D}_{3}$ in commercial whole eggs

\begin{tabular}{|c|c|c|c|}
\hline Origin & $\begin{array}{l}\text { Vitamin } D_{3} \\
(\mu \mathrm{g} / 100 \mathrm{~g})\end{array}$ & $\begin{array}{l}25(\mathrm{OH}) D_{3} \\
(\mu \mathrm{g} / 100 \mathrm{~g})\end{array}$ & Reference \\
\hline England & 1.6 & - & (Jackson, Shelton, \& Frier, 1982) $^{\mathrm{b}}$ \\
\hline England & 1.1 & - & (Sivell, Wenlock, \& Jackson, 1982) \\
\hline Japan & 1.3 & - & (Takeuchi, Okano, Teraoka, Murakami, \& Kobayashi, 1984) \\
\hline Finland & 1.7 & 0.32 & (Mattila et al., 1992; Mattila, Piironen, Uusi-rauva, \& Koivistoinen, 1993) \\
\hline Canada & 0.92 & 0.36 & $(\text { Bilodeau et al., 2011) })^{\mathrm{a}}$ \\
\hline Finland & 1.4 & 0.38 & (Mattila et al., 2011) \\
\hline USA & 2.46 & 0.56 & $(\mathrm{USDA}, 2019)^{\mathrm{a}}$ \\
\hline Russia & 2.2 & - & (Chirkin, Karpov, Selemenev, \& Shumskiy, 2013) \\
\hline Australia & 0.83 & 0.92 & (Liu et al., 2014) \\
\hline UK & 2.5 & 0.13 & $(\mathrm{PHE}, 2015)^{\mathrm{a}}$ \\
\hline Ireland & 1.1 & 1.0 & (Hayes et al., 2016) \\
\hline England & 1.7 & 0.5 & (Guo, Kliem, Lovegrove, \& Givens, 2017) $^{\mathrm{b}}$ \\
\hline Australia & 0.95 & 0.9 & (Dunlop et al., 2017) ${ }^{\mathrm{b}}$ \\
\hline Denmark & 1.37 & 0.44 & (DTU Food, 2018) $)^{\mathrm{a}, \mathrm{b}}$ \\
\hline
\end{tabular}

\begin{tabular}{l}
\hline Average (SD) $\quad \mathbf{1 . 5}(\mathbf{\pm 0 . 6}) \quad \mathbf{0 . 6}(\mathbf{\pm 0 . 3})$ \\
\hline SD = Standard deviation \\
- = not analysed \\
${ }^{\text {a }}$ Food composition table or data produced for a food composition table \\
b calculated average of results from free range, indoor and organic hens
\end{tabular}




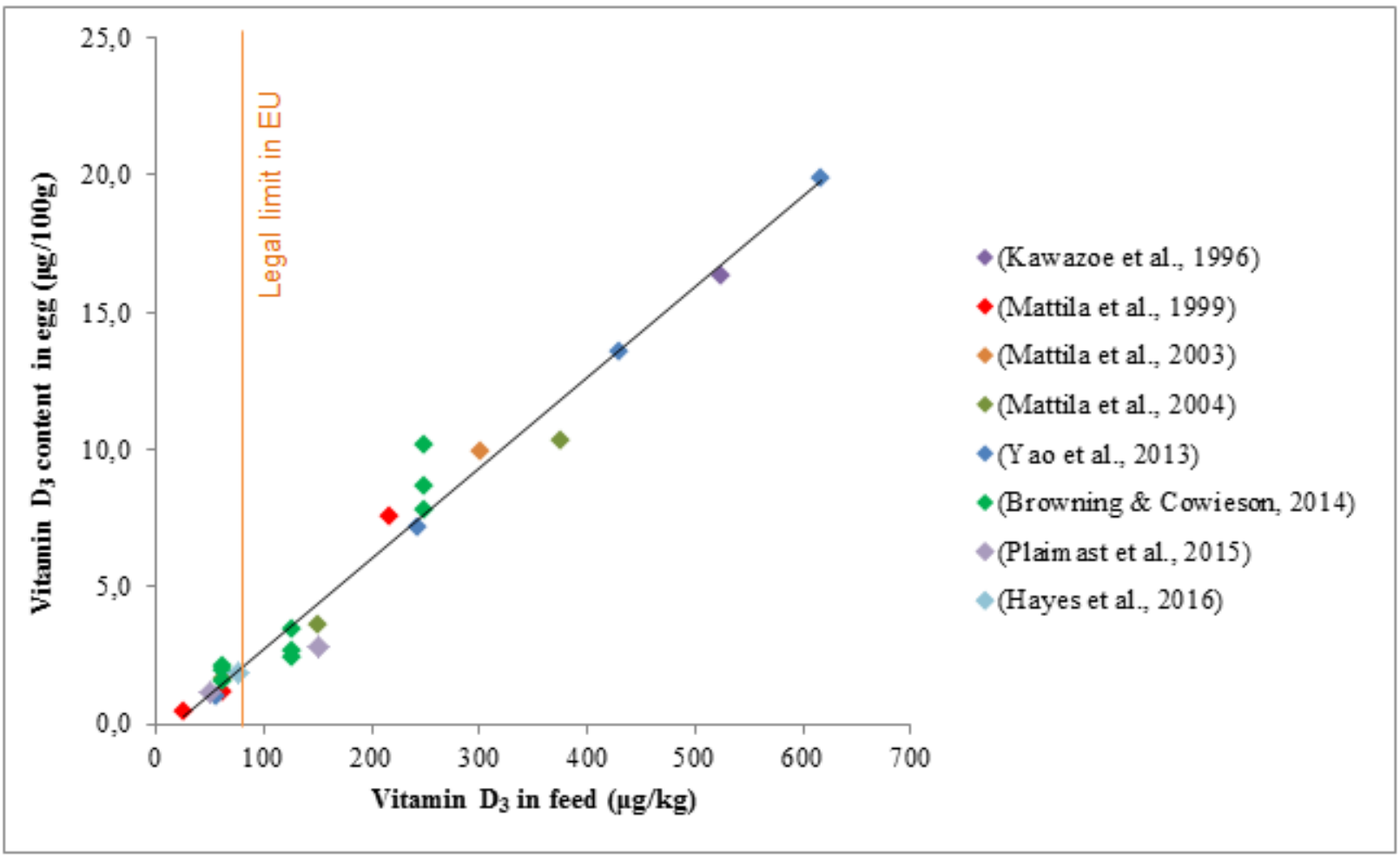




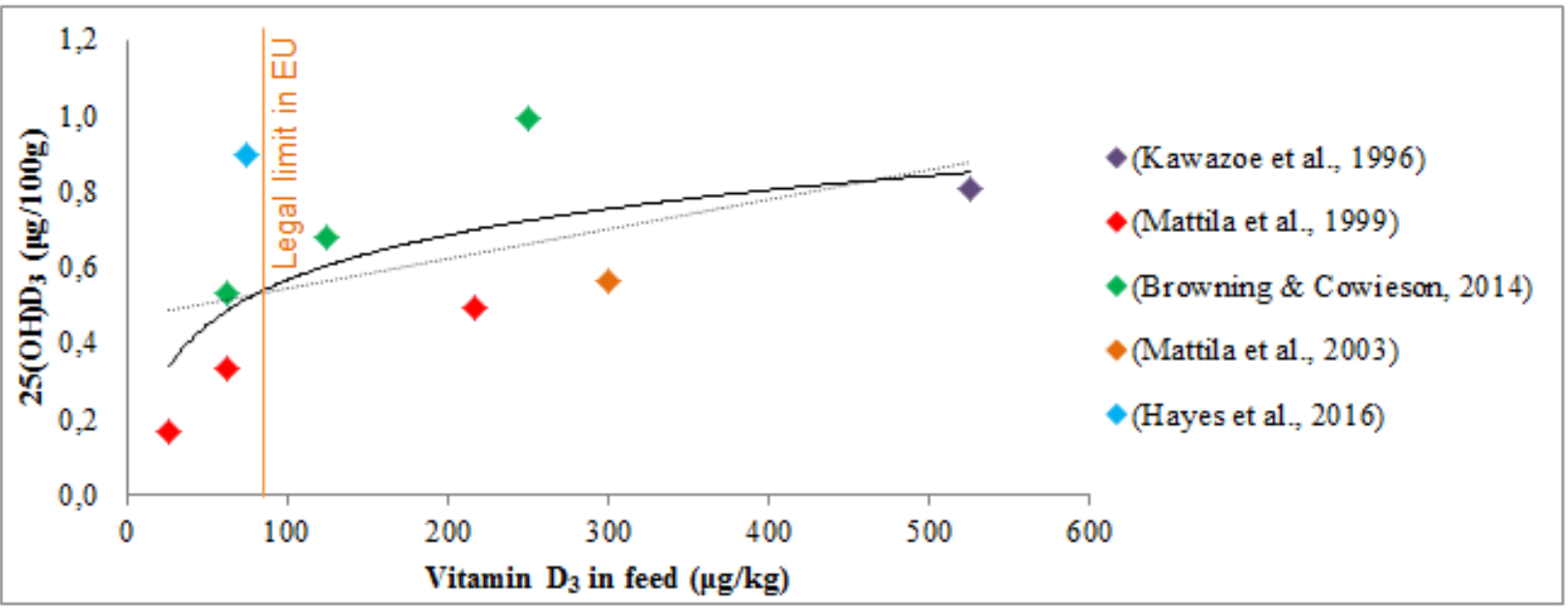




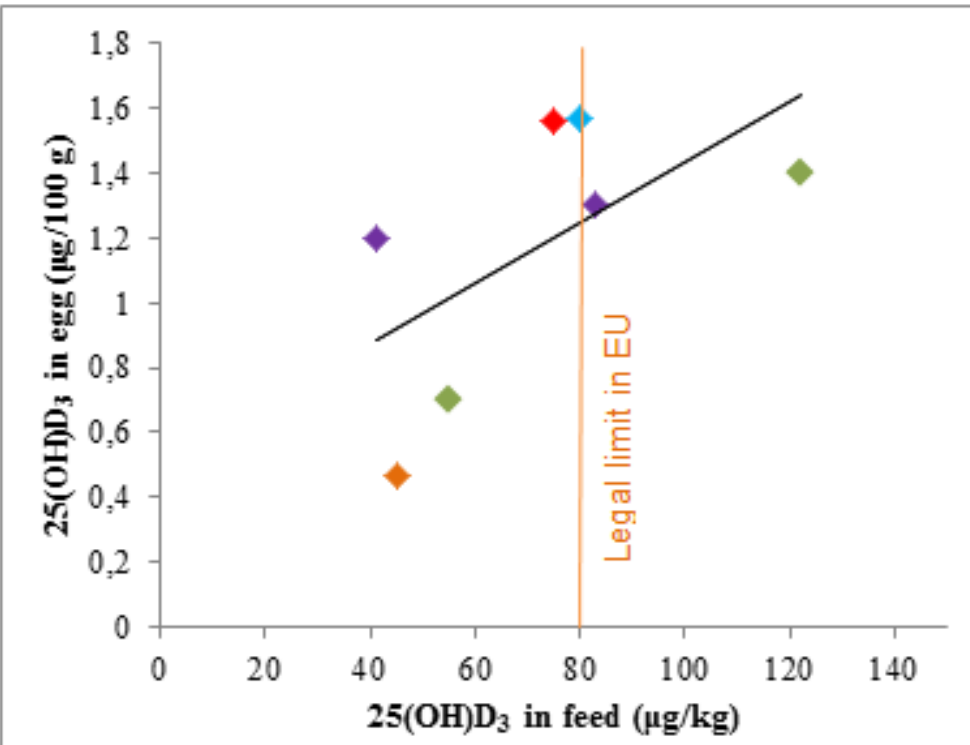

$\bullet$ (Terry et al., 1999)

$\bullet($ Koshy \& V an Der Slik, 1979)

- (Mattila et al., 2011)

$\bullet$ (Duffy et al., 2017)

$\bullet$ (Hayes et al., 2016) 


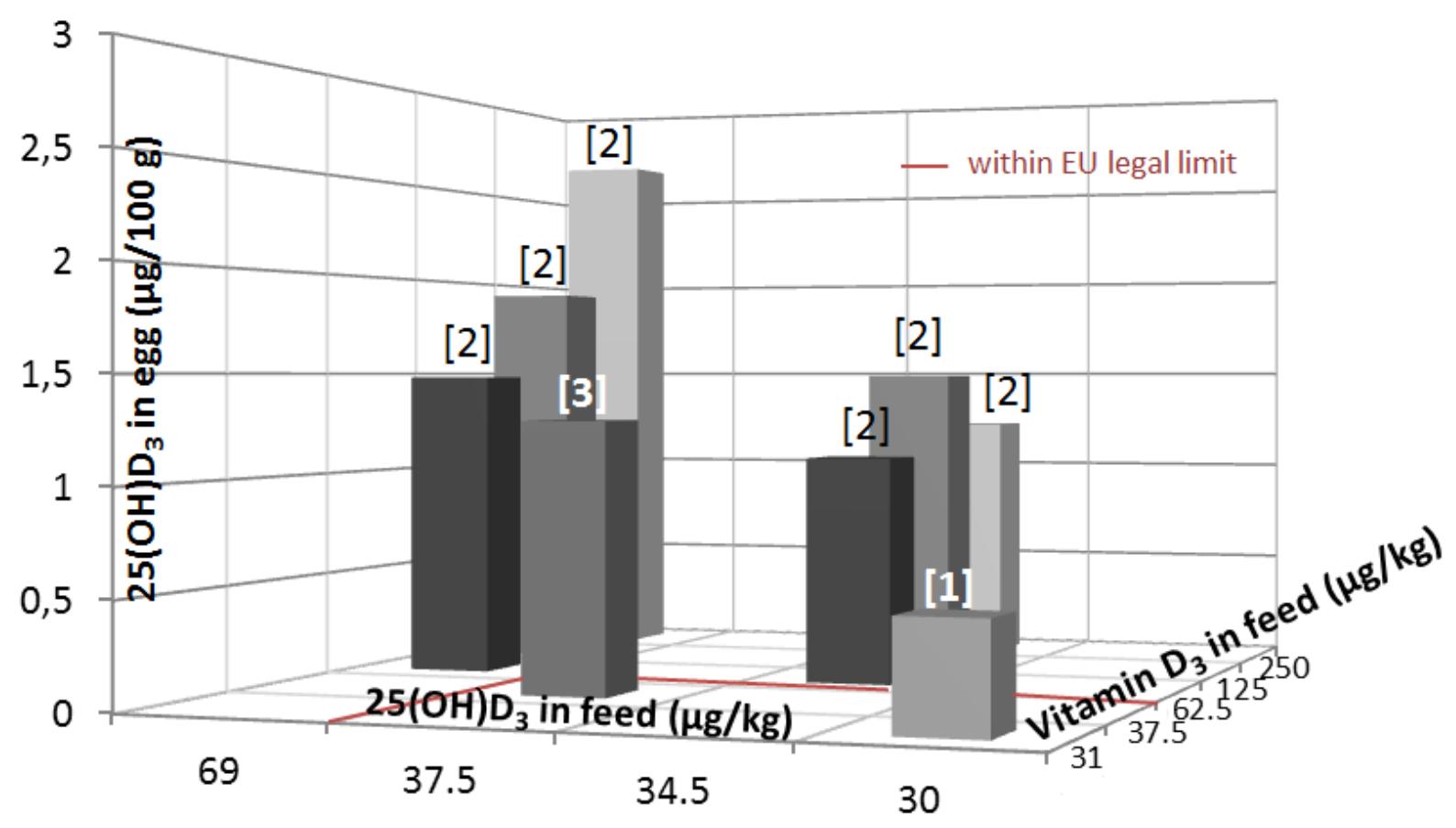




\section{Highlights}

- Three methods to produce eggs naturally enhanced with vitamin D was reviewed

- There is a linear inter-trial relationship between vitamin $\mathrm{D}_{3}$ in feed and vitamin $\mathrm{D}_{3}$ content in egg

- Feed is superior to UVB irradiation in regards to vitamin D enhancement in eggs

- Egg yolk can be vitamin D enhanced by direct exposure to UVB radiation

- Naturally enhanced eggs can contribute to increased vitamin D intake in the general population 